\title{
Brachial Plexus Injuries with Ulnar Musculocutaneous Transfer: 78 Cases Study Focused on Possible Postoperative Complications
}

\section{Transferência ulnarmusculocutânea nas lesões de plexo braquial: estudo de 78 casos quanto a possíveis complicações pós- operatórias}

\author{
Márcio Gargalhone Corrêa ${ }^{1}$ Márcio de Mendonça Cardoso ${ }^{1}$ Ricardo de Amoreira Gepp ${ }^{1}$ \\ Marco Rolando Sainz Quiroga ${ }^{1}$ Paulo Sérgio Siebra Beraldo ${ }^{1}$ \\ ${ }^{1}$ Rede Sarah de Hospitais de Reabilitação, Cruzeiro, DF, Brazil \\ Address for correspondence Márcio Gargalhone Corrêa, MD, Rede \\ SARAH de Hospitais de Reabilitação, Cruzeiro, DF, Brazil \\ Arq Bras Neurocir 2019;36:7-11. \\ (e-mail: mgargalhone@hotmail.com; 13719@sarah.br).
}

\begin{abstract}
Keywords

- nerve transfer

- ulnar nerve

- musculocutaneous nerve
\end{abstract}

\section{Resumo}

Objective To analyze 78 cases of brachial plexus injury submitted to the Oberlin technique between 2003 and 2012. The potential complications of this technique were analyzed, especially motor damage or hypoesthesia of the hand.

Method Medical records from patients with brachial plexus injuries at the levels of the C5-C6 and C5-C6-C7 vertebrae were retrospectively analyzed. Cases submitted to the Oberlin procedure with or without concomitant brachial plexus procedures between 2003 and 2012 were evaluated. The minimum follow-up period was of 1 year. In addition to the clinical examination, electromyography and magnetic resonance imaging (MRI) of the brachial plexus were used to diagnose and locate the nerve damage.

Results A total of 78 surgical patients met the inclusion criteria. Postoperative neurological changes, mostly transient, were observed in 18 patients. Hypoesthesia in the ulnar side of the hand was observed in seven cases; neuropathic pain in five cases; allodynia in four cases, and hand motor loss in two cases.

Conclusion Based on the results of the present case series, we conclude that there are few sequelae in the donor nerve territory compared with the benefit of the Oberlin technique on the recovery of elbow flexion after brachial plexus injuries.

Objetivo Analisar 78 casos de lesão de plexo braquial operados, submetidos à técnica de Oberlin entre 2003 e 2012. Possíveis complicações desta técnica foram analisadas, sobretudo possíveis prejuízos motores ou hipoestesia na mão.

Método Foi realizada uma análise retrospectiva de prontuários de pacientes com lesões do plexo braquial com lesão nos níveis das vértebras C5-C6 e C5-C6-C7. Foram analisados casos que haviam sido submetidos ao procedimento de Oberlin associado ou não a outros procedimentos concomitantes do plexo braquial entre 2003 e 2012 . O received June 1, 2016 accepted April 12, 2017
DOI https://doi.org/ 10.1055/s-0037-1602809. ISSN 0103-5355.
Copyright $\odot 2019$ by Thieme Revinter

Publicações Ltda, Rio de Janeiro, Brazil
License terms

c) $(1) \$$ 


\author{
Palavras-Chave \\ - transferência nervosa \\ - nervo ulnar \\ - nervo \\ musculocutâneo
}

\begin{abstract}
seguimento pós-operatório mínimo foi de 1 ano. Além do exame clínico, foram usadas para o diagnóstico e para a localização da lesão nervosa a eletroneuromiografia e a ressonância nuclear magnética do plexo braquial.

Resultados Foram obtidos 78 casos operados que preenchiam os critérios de inclusão. Alterações neurológicas pós-operatórias foram observadas em 18 pacientes, sendo, em sua grande maioria, transitórias. Hipoestesia na face ulnar da mão foi observada em sete casos; dores neuropáticas, em cinco; alodinia, em quatro; e perda motora na mão, em dois casos.

Conclusão Considerando os resultados da nossa casuística, concluímos que as sequelas no território do nervo doador são poucas diante do benefício que a técnica de Oberlin pode trazer à recuperação da flexão do cotovelo nas lesões do plexo braquial.
\end{abstract}

\section{Introduction}

The frequency of brachial plexus injuries has increased progressively, mostly due to motorcycle accidents. ${ }^{1}$ The roots of the C5 and C6 vertebrae are often affected, resulting in neurological deficits in the shoulder and elbow joints, but sparing hand function. ${ }^{2}$ Direct repairs with grafts are feasible only in postganglionic nerve lesions, while nerve transfers (neurotizations) $)^{2,3}$ are indicated for preganglionic lesions.

Until the early 1990s, the nerve transfer procedures for the treatment of upper brachial plexus roots lesions involved accessory nerves or intercostal nerves. ${ }^{4,5}$ Oberlin et al published an intraplexual nerve transfer technique using one or two ulnar nerve fascicles with terminoterminal neurorrhaphy to the biceps motor branches in an attempt to restore elbow flexion. ${ }^{3}$ Mackinnon et al described a variant of the original Oberlin technique in which, in addition to the ulnar-musculocutaneous transfer, a bundle of the median nerve was transferred to the motor branch for the brachial muscle. ${ }^{6,7}$

The Oberlin technique with the ulnar nerve as a donor has been shown to be simple to execute, and it is associated with few risks of severe sequelae due to the section of donor fascicles. ${ }^{8,9}$ However, there is a concern not to increase morbidity by using a functional donor nerve for the hand. Therefore, the present study aims to describe our experience with the original Oberlin technique, emphasizing its postoperative morbidity and the safety of the surgical approach.

\section{Method}

Medical records from patients submitted to the Oberlin procedure as surgical treatment of brachial plexus lesions involving the C5-C6 and C5-C6-C7 vertebrae were reviewed. The present study analyzed patients treated between 2003 and 2012, and with at least 1 year of postoperative follow-up. The variables analyzed included hand muscle strength and the presence of hypoesthesia, of sensitivity changes, and of neuropathic pain. These evaluations were performed by an independent examiner and correlated with factors such as the age of the patient age at the time of surgery, time elapsed between the trauma and the procedure, and the number of ulnar nerve fascicles used in the nerve transfer. The postoperative followup by the rehabilitation team occurred 30 days, 6 months, and 1 year after the discharge and, subsequently, annually. The functional assessment was performed according to the International Classification of Motor Function (Veterans Administration), detailed in - Table 1. Other procedures performed in these patients for the restoration of shoulder function, such as accessory nerve transfer to the suprascapular muscle, triceps motor branch transfer to the axillary nerve, and graft reconstructions, were not considered in the present study.

The surgical technique used was described by Oberlin (-Fig. 1). ${ }^{3}$ The patient was placed in the supine position with the affected upper limb in abduction. An incision was then made in the midline of the medial portion of the arm, between its middle and upper third. The space between the brachialis and the coracobrachialis biceps muscles was explored, identifying the motor branch to the biceps, which arises from the musculocutaneous nerve.

Next, the ulnar nerve was identified medially to the brachial artery, and the anterolateral aspect of its epineurium was incised (-Fig. 2). The motor fascicles for the flexor carpi ulnaris muscle were identified by a nerve microstimulator.

One or two motor fascicles were then sectioned, and a terminoterminal neurorrhaphy was performed between these ulnar nerve fascicles and the musculocutaneous branch to the biceps brachii using monofilament nylon 9.0, which can be reinforced with fibrin glue. After performing the suture, a test

Table 1 Motor function international classification (Veterans Administration)

\begin{tabular}{|l|l|}
\hline M0 & No motor activity \\
\hline M1 & $\begin{array}{l}\text { Visible or palpable muscle contraction, } \\
\text { but with no active movement }\end{array}$ \\
\hline M2 & Motor function present when gravity is eliminated \\
\hline M3 & $\begin{array}{l}\text { Active movement overcomes gravity, } \\
\text { but not resistance }\end{array}$ \\
\hline M4 & Active movement overcomes resistance \\
\hline M5 & Normal muscle strength \\
\hline
\end{tabular}




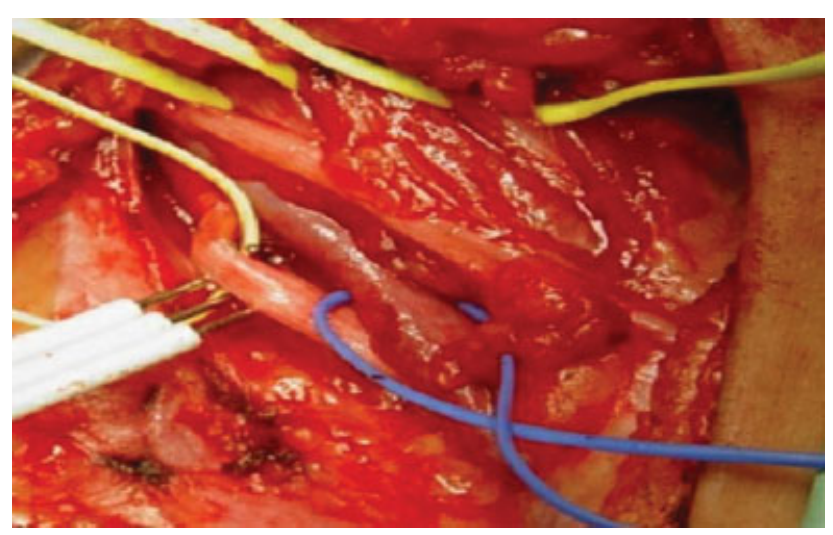

Fig. 1 Approach to the nerves of the arm. The ulnar nerve is observed medially, with the nerve stimulator, and the musculocutaneous nerve laterally, evidenced by the yellow strip.

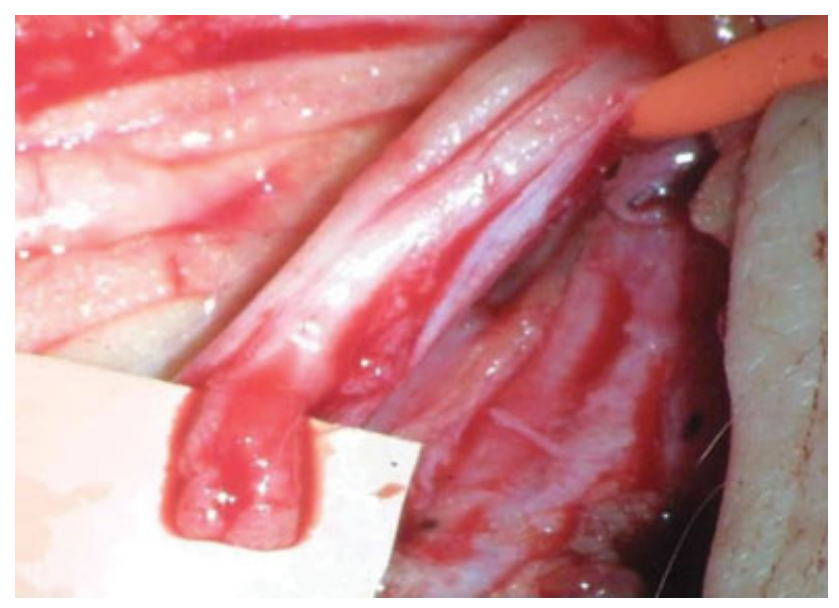

Fig. 2 The ulnar nerve epineurium was opened, and two fascicles were prepared and sectioned after the stimulation.

performed by moving the upper limb assured the absence of tension. Finally, the upper limb was immobilized in a sling for $\sim 30$ days.

\section{Results}

A total of 78 patients were analyzed, of which 74 were male. Children with obstetric brachial palsy and $<12$ years old with traumatic injuries were excluded from the study, mainly due to their difficulty to report sensitivity changes and pain characterization. The age of the patients at the time of the trauma ranged from 21 to 52 years old, and the average time elapsed until surgery was 7 months (ranging from 3 to 15 months). There were no intraoperative complications, such as dehiscence or infection of the surgical area. All of the patients were properly immobilized during the postoperative period. Postoperative complications related to the ulnar nerve included hypoesthesia in the ulnar face of the hand, neuropathic pain, allodynia, and loss of muscle strength in the hand. These changes, mostly transient, were observed in 18 patients ( $23 \%$ of the sample), all male (-Table 2 ).

Among the seven cases of hypoesthesia of the ulnar side of the hand, three remained without remission, that is, sustaining
Table 2 Postoperative complications related to the ulnar nerve

\begin{tabular}{|l|l|l|}
\hline Complication & Number of cases & Percentage \\
\hline Ulnar face hypoesthesia & 7 & $8.9 \%$ \\
\hline Neuropathic pain & 5 & $6.4 \%$ \\
\hline Allodynia & 4 & $5.1 \%$ \\
\hline Motor loss in the hand & 2 & $2.6 \%$ \\
\hline
\end{tabular}

Table 3 Hypoesthesia on the ulnar face of the hand

\begin{tabular}{|l|l|}
\hline Postoperative recovery time & Number of cases \\
\hline Without remission & 3 \\
\hline$<06$ months & 2 \\
\hline 7 months-1 year & 1 \\
\hline$>1$ year & 1 \\
\hline
\end{tabular}

some degree of the condition. Among the 4 cases that showed improvement, 2 recovered in $<6$ months postoperatively, one recovered after 7 months, and the other case took $>1$ year to achieve complete remission ( - Table 3 ). From the three cases without remission, two used one ulnar nerve fascicle for nerve transfer, and the third case used two fascicles. In 2 cases, the patient was operated 8 months post-trauma, and, in 1 case, 5 months had elapsed since the traumatic event. In the case with hand sensitivity remission after $>1$ year post-surgery, 2 fascicles had been used, and the time of evolution of the lesion at the time of the surgery was 6 months. There was no statistical correlation between the number of fascicles used and the occurrence of hypoesthesia.

Regarding neuropathic pain, only 1 case remained without remission, another 3 improved in $<6$ months, and 1 case presented complete recovery after $>1$ year ( - Table 4 ). Patients with pain were all male, aged between 22 and 41 years old at the time of the surgery, and, in all of the cases, an ulnar nerve bundle was used for nerve transfer. In the case with no remission, 1 fascicle had been used, and the time elapsed between the lesion and the surgery was 6 months.

Complaints of allodynia on the ulnar side of the hand persisted in only 1 patient after the surgery, and 3 cases presented complete remission in $<6$ months postoperatively (-Table 5). The age of the patients at the time of the surgery ranged from 21 to 36 years old; one of them was female; and all of the cases used an ulnar nerve bundle for the transfer. In the case that presented with sequelae, with no remission, the time elapsed between the trauma and the surgery was 8 months. Finally, there were 2 cases of wrist flexion and of digital deep flexion motor loss, but both were partial and transient, with

Table 4 Neuropathic pain

\begin{tabular}{|l|l|}
\hline Postoperative recovery time & Number of cases \\
\hline Without remission & 1 \\
\hline$<6$ months & 3 \\
\hline$>1$ year & 1 \\
\hline
\end{tabular}


Table 5 Alodinia

\begin{tabular}{|l|l|}
\hline Postoperative recovery time & Number of cases \\
\hline Without remission & 1 \\
\hline$<6$ months & 3 \\
\hline
\end{tabular}

complete remission in $\sim 30$ days post-surgery. The first patient, male, was 36 years old at the time of the trauma, and only 1 ulnar nerve bundle was used in the nerve transfer surgery, 60 days after the accident. The second patient, also male, was 27 years old, and only 1 ulnar nerve fascicle was used in the surgical transfer, 7 months post-trauma. Muscle strength was recovered 40 days post-surgery.

Therefore, we have noticed that most of the complications in our series were transient, requiring $<6$ months for complete recovery.

\section{Discussion}

Nerve transfers modified the approach to peripheral nerve lesions, especially to brachial plexus lesions. ${ }^{2}$ Transfers can use extraplexual or intraplexual donor nerves; in partial lesions, the plexus itself is used as a donor to the injured nerves. ${ }^{2,10,11}$ Nerve transfers to treat brachial plexus high lesions (at the levels of the C5-C6 and of the C5-C6-C7 vertebrae) were compared by Garg in a systematic review. ${ }^{12,13}$ The 31 analyzed studies demonstrated the superiority of nerve transfer compared with the direct approach to the brachial plexus with grafts. ${ }^{13}$

The literature reports excellent outcomes for the nerve transfer surgery for the recovery of elbow flexion. ${ }^{12,14-16}$ Rezende et al, analyzing 19 patients with lesions at the levels of the $\mathrm{C} 5-\mathrm{C} 6$ and of the $\mathrm{C} 5-\mathrm{C} 6-\mathrm{C} 7$ vertebrae submitted to the Oberlin procedure, noted that 8 patients showed improvement to grade 4 muscle strength, but with changes in the hand after surgery. ${ }^{16}$ These authors pointed out that the time elapsed between the lesion and the surgery was the main prognostic factor for functional recovery. ${ }^{16}$ A study conducted by a group from the Universidade de São Paulo and from the Universidad de Buenos Aires compared the nerve transfer with grafting and found that the former is associated with a superior outcome regarding muscular strength. ${ }^{11}$ Several authors consider that the great advantages of the Oberlin technique include promoting an effective motor response, not using the sural nerve as a graft, not sacrificing completely the donor nerve, and the proximity between the suture and the muscle requiring reinervation. ${ }^{2,11,17}$ Ulnarmusculocutaneous transfer surgery uses only one or two ulnar nerve fascicles, and no significant functional deficit has been observed. ${ }^{3,11}$ Few studies analyzed in detail the postsurgical deficits. ${ }^{5,15}$ The good outcomes associated with the Oberlin technique are due to its simplicity and to the proximity between the suture and the muscle requiring reinnervation; in addition, these outcomes were reproduced by several different authors. $3,4,9,15$

The surgical complications of this technique are few and, therefore, were barely studied in the reported case series. Concerns regarding the preservation of hand muscle strength, sensory deficit, and the risk of neuropathic pain are the main neurological complications researched in this surgery. 3,18

Intraoperative nerve stimulation avoids the random selection of ulnar nerve fascicles and is an essential aid to preserve fascicles with functional importance to the hand. ${ }^{7,8,18}$ The use of stimulation prevents motor deficit, but with no protective action against significant sensorial deficit or even against the development of neuropathic pain, which theoretically can be extremely disabling for the patient. A study with 36 patients, performed by Sungpet, showed no change in hand or wrist strength or sensitivity. ${ }^{19}$ This author used only 1 ulnar nerve fascicle and demonstrated a strength recovery to grade 3 in 34 patients with reinnervation starting at 3.3 months postoperatively. ${ }^{18}$

The use of the ulnar nerve as a donor has also been described in obstetric brachial palsies, in which there is a concern with the adequate development of the hand of the child. ${ }^{4,5}$ A study by Siqueira et al analyzed the growth of the hand and applied the Al-Quattan scale to evaluate the manual function of children submitted to the procedure. ${ }^{5}$ This study, in addition to demonstrating the efficiency of the surgical procedure, evidenced that the operated hand presented the same bone development compared with the unoperated one. Moreover, the Al-Quattan scale results were similar to the ones obtained before the surgery, proving that there was no motor deficit in the hands of children. ${ }^{5}$ This study is one of the few in the literature to prospectively analyze the risk of deficit development after sectioning the ulnar nerve in order to use it as a donor. ${ }^{5}$

In the present case series, as has already been stated, only two cases presented with motor loss, which was transient. A few cases had some type of permanent sequela (three cases of hypoesthesia on the ulnar side of the hand, one case of neuropathic pain, and one case of allodynia), all of which were sensorial. These data lead us to conclude that the Oberlin technique has a low morbidity and, therefore, is a safe technique for the patient, confirming the data found in the literature review. The present study is limited due to the fact that it is a retrospective analysis of surgical cases. Although hand motor function and sensitivity were analyzed by an independent examiner, since the present study is a retrospective analysis, especially in terms of sensitivity, it can provide a lower frequency if compared with a prospective study with an active search directed to sensitivity.

We conclude that the Oberlin technique is already classically recognized as effective for improving the elbow flexion function in high brachial plexus lesions, with a low risk of morbidity.

\section{Conflicts of Interest}

The authors have no conflicts of interest to declare.

\section{References}

1 Flores LP. [Epidemiological study of the traumatic brachial plexus injuries in adults]. Arq Neuropsiquiatr 2006;64(01):88-94

2 Siqueira MG, Martins RS. Surgical treatment of adult traumatic brachial plexus injuries: an overview. Arq Neuropsiquiatr 2011; 69(03):528-535 
3 Oberlin C, Béal D, Leechavengvongs S, Salon A, Dauge MC, Sarcy JJ. Nerve transfer to biceps muscle using a part of ulnar nerve for C5-C6 avulsion of the brachial plexus: anatomical study and report of four cases. J Hand Surg Am 1994;19(02):232-237

4 Al-Qattan MM, Thallaj A, Abdelhamid MM. Ulnar nerve to musculocutaneous nerve transfer in an ulnar ray-deficient infant with brachial plexus birth palsy: case report. J Hand Surg Am 2010;35 (09):1432-1434

5 Siqueira MG, Socolovsky M, Heise CO, Martins RS, Di Masi G. Efficacy and safety of Oberlin's procedure in the treatment of brachial plexus birth palsy. Neurosurgery 2012;71(06):1156-1160 , discussion 1161

6 Colbert SH, Mackinnon S. Posterior approach for double nerve transfer for restoration of shoulder function in upper brachial plexus palsy. Hand (N Y) 2006;1(02):71-77

7 Colbert SH, Mackinnon SE. Nerve transfers for brachial plexus reconstruction. Hand Clin 2008;24(04):341-361, v

8 Mackinnon SE, Colbert SH. Nerve transfers in the hand and upper extremity surgery. Tech Hand Up Extrem Surg 2008;12(01):20-33

9 Noaman HH, Shiha AE, Bahm J. Oberlin's ulnar nerve transfer to the biceps motor nerve in obstetric brachial plexus palsy: indications, and good and bad results. Microsurgery 2004;24(03):182-187

10 Martins RS, Siqueira MG, Heise CO, Teixeira MJ. Transfer of a fascicle from the posterior cord to the suprascapular nerve after injury of the upper roots of the brachial plexus: technical case report. Neurosurgery 2009;65(04):E823-E825, discussion E825

11 Socolovsky M, Martins RS, Di Masi G, Siqueira M. Upper brachial plexus injuries: grafts vs ulnar fascicle transfer to restore biceps muscle function. Neurosurgery 2012;71(2, Suppl Operative): ons227-ons232
12 Merrell GA, Barrie KA, Katz DL, Wolfe SW. Results of nerve transfer techniques for restoration of shoulder and elbow function in the context of a meta-analysis of the English literature. J Hand Surg Am 2001;26(02):303-314

13 Garg R, Merrell GA, Hillstrom HJ, Wolfe SW. Comparison of nerve transfers and nerve grafting for traumatic upper plexus palsy: a systematic review and analysis. J Bone Joint Surg Am 2011;93 (09):819-829

14 Bertelli JA, Ghizoni MF. Reconstruction of C5 and C6 brachial plexus avulsion injury by multiple nerve transfers: spinal accessory to suprascapular, ulnar fascicles to biceps branch, and triceps long or lateral head branch to axillary nerve. J Hand Surg Am 2004;29(01):131-139

15 Loy S, Bhatia A, Asfazadourian H, Oberlin C. [Ulnar nerve fascicle transfer onto to the biceps muscle nerve in $\mathrm{C} 5-\mathrm{C} 6$ or $\mathrm{C} 5-\mathrm{C} 6-\mathrm{C} 7$ avulsions of the brachial plexus. Eighteen cases]. Ann Chir Main Memb Super 1997;16(04):275-284

16 Rezende MR, Rabelo NT, Silveira CC, Petersen PA, Paula EJ, Mattar R. Results of ulnar nerve neurotization to biceps brachii muscle in brachial plexus injury. Acta Ortop Bras 2012;20(06):317-323

17 Martins RS, Barbosa RA, Siqueira MG, et al. Morbidity following sural nerve harvesting: a prospective study. Clin Neurol Neurosurg 2012;114(08):1149-1152

18 Sungpet A, Suphachatwong C, Kawinwonggowit V, Patradul A. Transfer of a single fascicle from the ulnar nerve to the biceps muscle after avulsions of upper roots of the brachial plexus. J Hand Surg [Br] 2000;25(04):325-328

19 Sungpet A, Suphachatwong C, Kawinwonggowit V. Transfer of one fascicle of ulnar nerve to functioning free gracilis muscle transplantation for elbow flexion. ANZ J Surg 2003;73(03):133-135 